\title{
Knowledge, Attitude and Awareness Levels of Dentists in Saudi Arabia Regarding COVID-19 Pandemic
}

\author{
Mohamad Abduljalil1 ${ }^{1}$ Burcu Gunal-Abduljalil², Alhasan Almasri ${ }^{3}$ \\ ${ }^{1,3}$ Department of Endodontics, Near East University, Mersin-10, Turkey. \\ ${ }^{2}$ Department of Prosthodontics, Near East University, Mersin-10, Turkey.
}

\section{ABSTRACT}

\section{BACKGROUND}

Covid-19 is a severe acute respiratory infection spreading worldwide. Sufficient dentists' knowledge, attitudes and correct practices are crucial for the prevention of Covid-19 in Saudi Arabia and all other countries. The objectives of this study were to understand the levels of knowledge, awareness and attitude of dentists in Saudi Arabia regarding Covid-19, and to investigate their treatment approaches in dental practices both before and during the pandemic.

\section{METHODS}

This questionnaire was prepared in May 2020 and distributed to dentists working in Saudi Arabia who were members at the Saudi Commission for Health Specialties and Saudi Dental Society. In order to pick the study subjects from our sampling frame, a simple random sampling methodology was used. The questionnaire comprised of a series of questions pertaining to sociodemographic characteristics, the knowledge and attitudes of dentists toward Covid-19, and dental approach before and during the pandemic. The data was statistically analysed to determine any significant association between the dentists' workplace and the measures followed in the dental clinic $(\mathrm{P}<0.05)$.

\section{RESULTS}

Four hundred and twelve dentists completed the questionnaire forming a response rate of $52 \%$. The majority of dentists showed a high level of knowledge, attitude and awareness regarding Covid-19. There was an association between the workplace and preventive measures in the dental clinic $(\mathrm{P}<0.05)$.

\section{CONCLUSIONS}

The majority of dentists in this survey had high knowledge and awareness of Covid19. Most of them followed the recommended preventive measures in their clinics. As Saudi Arabia still suffers from outbreaks of Covid-19 infection, continuous assessment of dentists' knowledge and practice is crucial.

\section{KEY WORDS}

Covid-19, Dentist, SARS-CoV-2, Saudi Arabia
Corresponding Author: Dr. Mohamad Abduljalil DDS, PhD, Department of Endodontics, Faculty of Dentistry, Near East University, Mersin - 10, Turkey.

E-mail: mohamad_abduljalil@hotmail.com

DOI: $10.14260 / \mathrm{jemds} / 2021 / 334$

How to Cite This Article: Abduljalil M, Gunal-Abduljalil B, Almasri A. Knowledge, attitude and awareness levels of dentists in saudi arabia regarding COVID- 19 pandemic. J Evolution Med Dent Sci 2021;10(21):1605-1610, DOI: 10.14260/jemds/2021/334

Submission 23-10-2020,

Peer Review 08-03-2021, Acceptance 16-03-2021, Published 24-05-2021.

Copyright (C) 2021 Mohamad Abduljalil et al. This is an open access article distributed under Creative Commons Attribution License [Attribution 4.0 International (CC $B Y 4.0)]$ 


\section{BACKGROUND}

Coronavirus disease 2019 (Covid-19) originated from the city of Wuhan, China. The outbreak of (Covid-19) spread rapidly to other parts of the world. ${ }^{1}$ The World Health Organisation (WHO) declared that this outbreak constituted a public health emergency of international concern on January $30,2020 .^{2}$ This novel coronavirus belongs to a family of single-stranded RNA viruses known as Coronaviridae. ${ }^{3}$ This family of viruses is known to be zoonotic or transmitted from animals to humans. ${ }^{4}$ Other examples of this family include severe acute respiratory syndrome corona virus (SARS-CoV), which was first identified in 2002, and middle east respiratory syndrome corona virus (MERS-CoV), which was first identified in 2012.5-7 The novel coronavirus was initially named 2019-novel coronavirus (2019-nCoV) and is officially known as severe acute respiratory syndrome corona virus 2 (SARS-CoV-2). ${ }^{8}$

The human-to-human transmission rate of SARS-CoV-2 has increased exponentially since mid-January 2020 and has spread unchecked to countries all over the world, particularly to Europe, North America and Asia-Pacific. Covid-19 was declared a universal epidemic or pandemic, by the WHO on March 11, 2020, with significant changes occurring in professional life as well due to the adverse conditions caused by the pandemic. Most symptoms of SARS-CoV-2 cases are mild or moderate in severity. Dry cough, fever, shortness of breath, and fatigue symptoms are observed in most cases; other symptoms can also manifest, such as muscle pain, head and throat pain, diarrhoea and nausea. ${ }^{9}$

It is an established fact that coronavirus is mainly transmitted through direct contact with the infected person, especially when that person coughs, sneezes or speaks. ${ }^{10}$ SARS-CoV-2 is also likely to spread in a relatively closed environment with high concentrations of aerosol. Thus, the environment during routine dental treatments increases the potential risk to dentists, assistant staff and patients. ${ }^{11}$ Dentists are at high risk of contracting Covid-19, due to faceto-face communication with patients; exposure to saliva, blood and other body fluids; and use of sharp instruments for the dental procedures. In fact, it has been stated that dentists are more likely to be affected by the new coronavirus disease than other doctors and nurses. ${ }^{12}$ In this critical era, understanding the spread of an airborne disease and its seriousness in dentistry necessitates application of special measures in addition to the standard precautions. ${ }^{13}$ Practical guidelines have been recommended for dentists and dental staff by the Centers for Disease Control and Prevention (CDC), the American Dental Association (ADA) and the WHO in order to control the spread of Covid-19.14-16

The Covid-19 pandemic spread to the Kingdom of Saudi Arabia (KSA) was on March 2, 2020, when the Ministry of Health confirmed the first case in the kingdom. ${ }^{17}$ From that date through October 17, 2020, the world has experienced more than 39 million confirmed cases of Covid-19, including approximately 1.1 million deaths, reported to the WHO. In Saudi Arabia, in the same time span, there have been 341,495 confirmed cases of Covid-19, with 5, 144 deaths. ${ }^{18}$ Since the KSA is one of the countries affected by the Covid-19 pandemic, it is important that dentists in the KSA follow these guidelines / recommendations.
This cross-sectional study aimed to understand the level of knowledge, awareness and attitude of dentists in Saudi Arabia regarding the Covid-19 pandemic, and to contribute to the scientific data in the field of dentistry by investigating treatment approach in dental practice before and during the pandemic.

\section{METHODS}

After ethical approval was obtained from the Scientific Research Ethics Evaluation Board (YDU / 2020 / 79 - 1078), an online questionnaire was designed in Google Forms. The study population consisted of dental health professionals working in different states of Saudi Arabia who were members at the Saudi Commission for Health Specialties and the Saudi Dental Society. This survey was distributed randomly to those dentists who were practicing dentistry in May 2020. In order to pick the study subjects from our sampling frame (list of all practicing dentists), sample size was taken based on the conveniences of the study.

The data was collected through two methods - 1) sending the questionnaire by email or other social media to the dentists; 2) getting in direct contact with participants at their workplace. The questionnaires were anonymous in order to maintain the privacy and confidentiality of all participants (and their information) in the study.

The survey questions were designed following a review of relevant literature, along with national and international guidelines from the World Health Organization (WHO), Centre for Disease Control (CDC), and Saudi Ministry of Health (MOH) regarding Covid-19.14-16 The questionnaire consisted of a series of questions pertaining to sociodemographic characteristics, the dentists' knowledge and attitudes of dentists toward Covid-19, and dental approaches before and during the pandemic.

The questions were multiple-choice, and the questionnaire was divided into four sections: dentists' demographic and profession-related characteristics, dentists' awareness regarding SARS-CoV-2 data, dental approaches before and during the pandemic, and infection control measures for preventing Covid-19.

\section{Statistical Analysis}

The data was entered into Excel (Microsoft Corporation, Redmond, WA, USA) and processed with the statistical software International Business Machines Statistical Package for the Social Sciences (IBM SPSS) Statistics (version 22.0; IBM Corp., Armonk, NY, USA). Chi-square tests were used to determine significant associations between the dentist's workplace and the measures followed in the dental clinic. For statistical analyses, $\mathrm{P}$ values of $<0.05$ were accepted as statistically significant.

\section{RESULTS}

A total of 412 dentists completed the questionnaire forming a response rate of approximately $52 \%$. Table 1 summarises the characteristics of the dentists enrolled in the study. Two 
hundred twenty-eight of the respondents were men, and 184 were women. Age was divided into two sections: < $30(26.5 \%)$ and $\geq 30(73.5 \%)$. The majority of the participants were general practitioners (65.3\%) and only $15.5 \%$ of them were academicians. The respondents worked in different health sectors, although most of them worked in special clinics. The dentists ranged widely in their years of professional experience.

\begin{tabular}{|c|c|c|}
\hline & Variable & $\begin{array}{l}\text { Number } \\
\text { (Percent) }\end{array}$ \\
\hline \multirow{2}{*}{ Age } & $<30$ & $109(26.5 \%)$ \\
\hline & $\geq 30$ & $303(73.5 \%)$ \\
\hline \multirow{2}{*}{ Gender } & Male & $228(55.3 \%)$ \\
\hline & Female & $184(44.7 \%)$ \\
\hline \multirow{2}{*}{ Specialty in dentistry } & General practitioner & $269(65.3 \%)$ \\
\hline & Specialist & 143 (34.7 \%) \\
\hline \multirow{2}{*}{ Occupation } & Dental practitioner & $348(84.5 \%)$ \\
\hline & Academician & $64(15.5 \%)$ \\
\hline \multirow{5}{*}{ Health sector } & Governmental hospital & $56(13.6 \%)$ \\
\hline & Private hospital & $117(28.4 \%)$ \\
\hline & Private clinic & $151(36.6 \%)$ \\
\hline & Governmental university & $37(8.9 \%)$ \\
\hline & Private university & $51(12.5 \%)$ \\
\hline \multirow{4}{*}{$\begin{array}{l}\text { Years of experience in the } \\
\text { profession }\end{array}$} & 1 - 5 years & 137 (33.2 \%) \\
\hline & $6-10$ years & $101(24.5 \%)$ \\
\hline & $11-15$ years & $90(21.9 \%)$ \\
\hline & $\geq 16$ years & $84(20.4 \%)$ \\
\hline
\end{tabular}

\begin{tabular}{|c|c|c|}
\hline & Variable & $\begin{array}{l}\text { Number } \\
\text { (Percent) }\end{array}$ \\
\hline \multirow{10}{*}{$\begin{array}{l}\text { Symptoms } \\
\text { of Covid-19 }\end{array}$} & Fever & $408(99 \%)$ \\
\hline & Cough & $391(94.9 \%)$ \\
\hline & Difficulty breathing & $403(97.8 \%)$ \\
\hline & Fatigue & $307(73.8 \%)$ \\
\hline & Muscle or body aches & $333(80.8 \%)$ \\
\hline & Headache & $356(86.4 \%)$ \\
\hline & Loss of taste or smell & $356(86.4 \%)$ \\
\hline & Congestion or runny nose & $265(64.3 \%)$ \\
\hline & Nausea or vomiting & $219(53.2 \%)$ \\
\hline & Diarrhoea & $246(59.7 \%)$ \\
\hline \multirow{5}{*}{$\begin{array}{c}\text { Transmission } \\
\text { methods } \\
\text { of Covid-19 }\end{array}$} & Between people who are in close contact & $386(93.7 \%)$ \\
\hline & Infected person coughs & $388(64.2 \%)$ \\
\hline & Infected person sneezes & $385(93.4 \%)$ \\
\hline & Infected person talks & $317(76.9 \%)$ \\
\hline & Touching the infected surfaces & $405(98.3 \%)$ \\
\hline \multirow{4}{*}{$\begin{array}{l}\text { Incubation } \\
\text { period }\end{array}$} & 2 - 14 days & $282(68.4 \%)$ \\
\hline & 1 - 7 days & $6(1.5 \%)$ \\
\hline & 7 - 14 days & $69(16.7 \%)$ \\
\hline & $14-21$ days & $55(13.3 \%)$ \\
\hline \multirow{9}{*}{$\begin{array}{l}\text { People in } \\
\text { high risk to } \\
\text { get infected }\end{array}$} & $\begin{array}{c}\text { Older adults } \\
\text { (more than } 65 \text { years) }\end{array}$ & $281(68.2 \%)$ \\
\hline & People with asthma & $270(65.5 \%)$ \\
\hline & People with liver diseases & $142(34.5 \%)$ \\
\hline & People with chronic lung disease & $269(65.3 \%)$ \\
\hline & People with diabetes & $205(49.8 \%)$ \\
\hline & People who have serious heart conditions & $229(55.6 \%)$ \\
\hline & People with severe obesity & $129(31.3 \%)$ \\
\hline & People who are immunocompromised & $254(61.7 \%)$ \\
\hline & All of them are in high risk & $215(52.2 \%)$ \\
\hline \multirow{3}{*}{$\begin{array}{c}\text { N95 masks } \\
\text { are available } \\
\text { in different sizes }\end{array}$} & True & $276(67 \%)$ \\
\hline & Wrong & $29(7 \%)$ \\
\hline & No idea & $107(26 \%)$ \\
\hline \multirow{4}{*}{$\begin{array}{c}\text { When do you } \\
\text { change N95 mask if } \\
\text { you use it? }\end{array}$} & After every patient & $64(15.5 \%)$ \\
\hline & Once a day & $190(46.1 \%)$ \\
\hline & When becomes dirty or wet & $35(8.5 \%)$ \\
\hline & After using devices produce aerosol & $68(16.5 \%)$ \\
\hline \multirow{3}{*}{$\begin{array}{l}\text { In addition to N95, } \\
\text { FDA suggested } \\
\text { using of Equivalent } \\
\text { masks such as KN / } \\
\text { KP95, PFF2, P2, DS } \\
\text { / DL2, KOREAN } \\
\text { SPECIAL 1st }\end{array}$} & True & $251(60.9 \%)$ \\
\hline & Wrong & $6(1.5 \%)$ \\
\hline & No idea & $155(37.6 \%)$ \\
\hline
\end{tabular}

In the second section of the questionnaire, questions about Covid-19 information were prepared and asked the participants to investigate their awareness. The questions and the dentists' responses are shown in Table 2. Most participants stated that they knew the main symptoms of SARS-CoV-2 (fever, cough, difficulty breathing, fatigue, muscle or body aches, loss of taste or smell), and half of the respondents also knew the other symptoms in addition to the main ones which were confirmed by CDC (headache, congestion or runny nose, nausea or vomiting, diarrhoea). Approximately $90 \%$ of the participants knew the transmission methods of Covid-19 including people who are in close contact, infected person coughs, infected person sneezes, infected person talks, touching the infected surfaces. When asked about the incubation period, $68.4 \%$ of the respondents knew that the period was 2 - 14 days.

\begin{tabular}{|c|c|c|}
\hline \multicolumn{2}{|c|}{ Variable } & \multirow{2}{*}{$\begin{array}{c}\text { Number } \\
\text { (Percent) } \\
394(95.6 \%)\end{array}$} \\
\hline \multirow{8}{*}{$\begin{array}{l}\text { Equipment used before Covid-19 } \\
\text { pandemic period }\end{array}$} & Surgical mask & \\
\hline & N95 mask & $24(5.8 \%)$ \\
\hline & Gloves & $396(96.1 \%)$ \\
\hline & Eye protection glasses & $335(81.3 \%)$ \\
\hline & Disposable lab coat & $296(71.8 \%)$ \\
\hline & Face shield & $286(69.4 \%)$ \\
\hline & Dental cap & $122(29.6 \%)$ \\
\hline & Shoes cover & $227(55.1 \%)$ \\
\hline \multirow{8}{*}{$\begin{array}{l}\text { Equipment used during Covid-19 } \\
\text { pandemic period }\end{array}$} & Surgical mask & $193(46.8 \%)$ \\
\hline & N95 mask & $298(72.3 \%)$ \\
\hline & Gloves & $405(98.3 \%)$ \\
\hline & Eye protection glasses & $376(91.3 \%)$ \\
\hline & Disposable lab coat & $396(96.1 \%)$ \\
\hline & Face shield & $394(95.6 \%)$ \\
\hline & Dental cap & $311(75.5 \%)$ \\
\hline & Shoes cover & $367(89.1 \%)$ \\
\hline \multirow{3}{*}{$\begin{array}{l}\text { Frequency of washing the lab coat } \\
\text { before Covid-19 pandemic }\end{array}$} & Disposable lab coat (one use) & $182(44.2 \%)$ \\
\hline & Once a day & $129(31.3 \%)$ \\
\hline & 2 - 3 times a week & $90(21.8 \%)$ \\
\hline \multirow{3}{*}{$\begin{array}{l}\text { Frequency of washing the lab coat } \\
\text { during Covid-19 pandemic }\end{array}$} & Disposable lab coat (one use) & $323(78 \%)$ \\
\hline & Once a day & $84(20 \%)$ \\
\hline & 2 - 3 times a week & $5(2 \%)$ \\
\hline \multirow{2}{*}{$\begin{array}{l}\text { Going out somewhere with the same } \\
\text { clothes worn in the clinic before } \\
\text { Covid-19 pandemic period }\end{array}$} & Yes & $305(74 \%)$ \\
\hline & No & $107(26 \%)$ \\
\hline \multirow{2}{*}{$\begin{array}{l}\text { Going out somewhere with the same } \\
\text { clothes worn in the clinic during } \\
\text { Covid-19 pandemic period }\end{array}$} & Yes & $17(4.1 \%)$ \\
\hline & No & $395(95.9 \%)$ \\
\hline \multirow{4}{*}{$\begin{array}{l}\text { Frequency of changing the surgical } \\
\text { mask before Covid-19 }\end{array}$} & After every patient & $341(82.8 \%)$ \\
\hline & After 2 - 3 patient & $31(7.5 \%)$ \\
\hline & Once a day & $15(3.6 \%)$ \\
\hline & $\begin{array}{l}\text { After using devices produce } \\
\text { aerosol }\end{array}$ & $22(5.3 \%)$ \\
\hline \multirow{4}{*}{$\begin{array}{l}\text { Frequency of changing the surgical } \\
\text { mask during Covid-19 }\end{array}$} & After every patient & $379(92 \%)$ \\
\hline & After $2-3$ patient & $6(1.5 \%)$ \\
\hline & Once a day & $8(1.9 \%)$ \\
\hline & $\begin{array}{c}\text { After using devices produce } \\
\text { aerosol }\end{array}$ & $13(3.2 \%)$ \\
\hline \multirow{4}{*}{$\begin{array}{l}\text { Working hour changing after Covid- } \\
\qquad 19\end{array}$} & Working hours decreased & $300(72.8 \%)$ \\
\hline & Working hour increased & $0(0 \%)$ \\
\hline & Same working hours & $10(2.4 \%)$ \\
\hline & The clinic completely closed & $102(24.8 \%)$ \\
\hline $\begin{array}{r}\text { ble Dentists' Ap } \\
\text { before and d }\end{array}$ & $\begin{array}{l}\text { aches in the Dental Pra } \\
g \text { Covid-19 Pandemic. }\end{array}$ & ices \\
\hline
\end{tabular}

The CDC has stated that older adults, people with asthma, liver diseases, chronic lung disease, diabetes, serious heart conditions, severe obesity and people who are immunocompromised are at higher risk for severe illness and need to take extra precautions. ${ }^{15}$ These high-risk groups were identified by half of the dentists in this survey. Additionally, 67 $\%$ of the respondents knew that the N95 mask has different sizes, and about $61 \%$ of them reported that the following statement is true "The Food and Drug Administration (FDA) recommended using masks equivalent to N95 quality during the Covid-19 period such as KN / KP95, PFF2, P2, DS / DL2, 


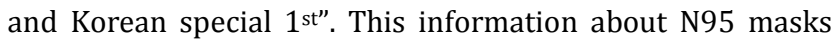
was derived from the FDA. ${ }^{19}$ The third part of the questionnaire consisted of questions about the dentists' approaches in their dental practices, both before and during Covid-19 pandemic. The first question was about the equipment used by dentists to prevent infections. Three hundred ninety-four dentists stated using surgical masks before the pandemic; this number decreased during the pandemic, and the use of N95 mask increased (72.3\%). Respondents' use of other protective equipment such as eye protection glasses, disposable lab coats, face shields, dental caps and shoe covers increased after the outbreak of the pandemic. The pre-pandemic frequencies of washing the lab coat were increased by washing the lab coat every day, washing 2 - 3 times a week, or using a disposable lab coat. However, $78 \%$ of the respondents stated that they use disposable lab coats during the pandemic. Approximately 96 $\%$ of the dentists stated that they do not leave the clinic with the same lab coat during the pandemic. Majority of the participants reported changing the surgical mask after every patient, both before and during the pandemic. The working hours of 300 respondents decreased after the pandemic outbreak (Table 3).

The final part of the questionnaire included questions about the dentists' attitudes in preventing Covid-19 infection in the clinic (Table 4). The CDC suggests measuring the body temperature of workers in dental clinics twice a day. $46.4 \%$ of the respondents in the study measured temperature once a day and $47.8 \%$ measured temperature twice a day. The dentists were asked about the dental procedures performed in their clinics and most of them (81.1\%) stated that they performed procedures only for the emergency cases (pain, swelling or trauma), while $31.6 \%$ stopped all dental procedures during Covid-19. The measures taken for preventing Covid-19 transmission in dental clinics were asked and the responses are summarised in Table 4. Of the participants, $44.2 \%$ followed all the preventive measures in the clinic which was suggested by the CDC.

The last question asked was whether the dentists followed any prevention measures when using devices that produce aerosol.
Table 5 shows the association between dentists' workplaces and the measures followed in the dental clinic. Chisquare tests showed that there were associations between the dentists' workplace and the measures except for avoiding intra-oral $x$-rays and making the patients rinse their mouth before starting the treatment with P values of 0.418 and 0.716 , respectively.

\begin{tabular}{|c|c|c|}
\hline \multicolumn{2}{|r|}{ Variable } & Number (Percent) \\
\hline \multirow{3}{*}{$\begin{array}{l}\text { How many } \\
\text { times do you } \\
\text { check the } \\
\text { dental workers } \\
\text { temperature? }\end{array}$} & Once a day & $191(46.4 \%)$ \\
\hline & 2 times a day & $197(47.8 \%)$ \\
\hline & Once a week & $9(2.2 \%)$ \\
\hline \multirow{9}{*}{$\begin{array}{c}\text { The dental } \\
\text { procedures } \\
\text { that you } \\
\text { perform during } \\
\text { Covid-19 } \\
\text { period }\end{array}$} & Only emergency cases & $334(81.1 \%)$ \\
\hline & $\begin{array}{l}\text { Stopped all dental procedure during } \\
\text { Covid-19 }\end{array}$ & $130(31.6 \%)$ \\
\hline & Restorative fillings & $32(7.8 \%)$ \\
\hline & Non-emergency endodontic treatment & $23(5.6 \%)$ \\
\hline & Non-emergency tooth extraction & $21(5.1 \%)$ \\
\hline & Periodontal scaling & $16(3.9 \%)$ \\
\hline & Prosthodontic & $12(2.9 \%)$ \\
\hline & Orthodontic treatment & $11(2.7 \%)$ \\
\hline & Surgical procedures & $32(7.8 \%)$ \\
\hline \multirow{10}{*}{$\begin{array}{c}\text { Infection } \\
\text { control } \\
\text { measures in the } \\
\text { dental clinic } \\
\text { during Covid- } \\
19 \text { period }\end{array}$} & $\begin{array}{l}\text { Taking the main complaint from the patients } \\
\text { via telephone before accepting them in the } \\
\text { clinic }\end{array}$ & $318(77.2 \%)$ \\
\hline & $\begin{array}{l}\text { Allow only the patient to enter the clinic } \\
\text { without their relatives }\end{array}$ & $370(89.8 \%)$ \\
\hline & $\begin{array}{c}\text { Taking the patient's temperature and asking } \\
\text { about any Covid-19 symptoms within } 14 \\
\text { days }\end{array}$ & $359(87.1 \%)$ \\
\hline & $\begin{array}{l}\text { Provide the social distance }(2 \mathrm{~m}) \text { between } \\
\text { patients in the waiting room }\end{array}$ & $271(65.8 \%)$ \\
\hline & Avoid intraoral $\mathrm{x}$-rays & $293(71.1 \%)$ \\
\hline & $\begin{array}{l}\text { Make the patients to rinse their mouth with } \\
\text { hydrogen peroxide or povidone before } \\
\text { starting the treatment }\end{array}$ & $187(45.4 \%)$ \\
\hline & $\begin{array}{l}\text { Avoid using devices produce aerosol as much } \\
\text { as possible }\end{array}$ & $319(77.4 \%)$ \\
\hline & $\begin{array}{l}\text { Heat sterilisation of the handpiece if used } \\
\text { after every patient }\end{array}$ & $341(82.8 \%)$ \\
\hline & $\begin{array}{l}\text { Sufficient ventilation after every patient in } \\
\text { the clinic }\end{array}$ & $352(85.4 \%)$ \\
\hline & Using absorbable sutures in surgical cases & $254(61.7 \%)$ \\
\hline \multirow{4}{*}{$\begin{array}{l}\text { If the devises } \\
\text { produce } \\
\text { aerosol, the } \\
\text { following } \\
\text { measures are } \\
\text { applied }\end{array}$} & 4-handed technique (with the nurse) & $311(75.5 \%)$ \\
\hline & Using high vacuum suctions & $330(80.1 \%)$ \\
\hline & Using rubber dam & $285(69.2 \%)$ \\
\hline & I do nothing & $106(25.7 \%)$ \\
\hline & $\begin{array}{l}\text { Dentists' Attitude Toward Dentc } \\
\text { in Preventing Covid-19 Infect }\end{array}$ & ocedures \\
\hline
\end{tabular}

\begin{tabular}{|c|c|c|c|c|c|c|c|}
\hline & & $\begin{array}{c}\text { Governmental } \\
\text { Hospital }\end{array}$ & $\begin{array}{c}\text { Private } \\
\text { Hospital }\end{array}$ & $\begin{array}{l}\text { Private } \\
\text { Clinic }\end{array}$ & $\begin{array}{c}\text { Governmental } \\
\text { University }\end{array}$ & $\begin{array}{c}\text { Private } \\
\text { University }\end{array}$ & $\begin{array}{c}\mathbf{P} \\
\text { Values }\end{array}$ \\
\hline \multirow{2}{*}{$\begin{array}{l}\text { 1. Taking the main complaint from the patients via } \\
\text { telephone before accepting them in the clinic }\end{array}$} & Yes & $39(69.6 \%)$ & $77(65.8 \%)$ & 118(78.1\%) & 37 (100 \%) & 47 (92.1\%) & \multirow{2}{*}{$0.000^{*}$} \\
\hline & No & $17(30.4 \%)$ & $40(34.2 \%)$ & $33(21.9 \%)$ & $0(0.0 \%)$ & $4(7.9 \%)$ & \\
\hline \multirow{2}{*}{$\begin{array}{l}\text { 2. Allow only the patient to enter the clinic without their } \\
\text { relatives }\end{array}$} & Yes & $56(100 \%)$ & $95(81.2 \%)$ & $139(92.1 \%)$ & 33 (89.2 \%) & 47 (92.2 \%) & \multirow{2}{*}{$0.002^{*}$} \\
\hline & No & $0(0.0 \%)$ & $22(18.8 \%)$ & $12(7.9 \%)$ & $4(10.8 \%)$ & $4(7.8 \%)$ & \\
\hline \multirow{2}{*}{$\begin{array}{l}\text { 3. Taking the patient's temperature and asking about any } \\
\text { Covid- } 19 \text { symptoms within } 14 \text { days }\end{array}$} & Yes & $44(78.6 \%)$ & $96(82.1 \%)$ & $133(88 \%)$ & 33 (89.2 \%) & $51(100 \%)$ & \multirow{2}{*}{$0.015^{*}$} \\
\hline & No & $12(21.4 \%)$ & $21(17.9 \%)$ & $18(12 \%)$ & $4(10.8 \%)$ & $0(0.0 \%)$ & \\
\hline \multirow{2}{*}{$\begin{array}{l}\text { 4. Provide the social distance }(2 \mathrm{~m}) \text { between patients in } \\
\text { the waiting room }\end{array}$} & Yes & $27(48.2 \%)$ & $60(51.3 \%)$ & $123(81.5 \%)$ & $22(59.5 \%)$ & $39(76.5 \%)$ & \multirow{2}{*}{$0.000^{*}$} \\
\hline & No & $29(51.8 \%)$ & $57(48.7 \%)$ & $28(18.5 \%)$ & $15(40.5 \%)$ & $12(23.5 \%)$ & \\
\hline \multirow{2}{*}{ 5. Avoid intra-oral x-rays } & Yes & $40(71.4 \%)$ & $76(65 \%)$ & $109(72.2 \%)$ & $29(78.4 \%)$ & 39 (76.5 \%) & \multirow{2}{*}{0.418} \\
\hline & No & $16(28.6 \%)$ & $41(35 \%)$ & $42(27.8 \%)$ & $8(21.6 \%)$ & $12(23.5 \%)$ & \\
\hline \multirow{2}{*}{$\begin{array}{l}\text { 6. Make the patients to rinse their mouth with hydrogen } \\
\text { peroxide or povidone before starting the treatment }\end{array}$} & Yes & $24(42.9 \%)$ & $48(41 \%)$ & $73(48.3 \%)$ & $19(51.4 \%)$ & $23(45.1 \%)$ & \multirow[b]{2}{*}{0.716} \\
\hline & No & $32(57.1 \%)$ & $69(59 \%)$ & 78 (51.7\%) & $18(48.6 \%)$ & $28(54.9 \%)$ & \\
\hline \multirow{2}{*}{$\begin{array}{l}\text { 7. Avoid using devices which produce aerosol as much as } \\
\text { possible }\end{array}$} & Yes & 48 (85.7\%) & $72(61.5 \%)$ & $119(78.8 \%)$ & 33 (89.2 \%) & 47 (92.2 \%) & \multirow{2}{*}{$0.000^{*}$} \\
\hline & No & $8(14.3 \%)$ & $45(38.5 \%)$ & $32(21.2 \%)$ & $4(10.8 \%)$ & $4(7.8 \%)$ & \\
\hline \multirow{2}{*}{$\begin{array}{l}\text { 8. Heat sterilisation of the hand piece if used after every } \\
\text { patient }\end{array}$} & Yes & $40(71.4 \%)$ & $90(76.9 \%)$ & $142(94 \%)$ & $26(70.3 \%)$ & $43(84.3 \%)$ & \multirow{2}{*}{$0.000^{*}$} \\
\hline & No & $16(28.6 \%)$ & $27(23.1 \%)$ & $9(6 \%)$ & $11(29.7 \%)$ & $8(15.7 \%)$ & \\
\hline \multirow{2}{*}{ 9. Sufficient ventilation after every patient in the clinic } & Yes & $56(100 \%)$ & $96(82.1 \%)$ & 124(82.1 \%) & $33(89.2 \%)$ & $43(84.3 \%)$ & \multirow{2}{*}{$0.014^{*}$} \\
\hline & No & $0(0 \%)$ & $21(17.9 \%)$ & $27(17.9 \%)$ & $4(10.8 \%)$ & $8(15.7 \%)$ & \\
\hline \multirow{2}{*}{ 10. Using absorbable sutures in surgical cases } & Yes & $40(71.4 \%)$ & $54(46.2 \%)$ & $91(60.3 \%)$ & $26(70.3 \%)$ & $43(84.3 \%)$ & \multirow{2}{*}{$0.000^{*}$} \\
\hline & No & $16(28.6 \%)$ & $63(53.8 \%)$ & 60 (39.7 \%) & $11(29.7 \%)$ & $(15.7 \%)$ & \\
\hline
\end{tabular}




\section{DISCUSSION}

The current study investigated the attitude and awareness levels of dentists in the Kingdom of Saudi Arabia regarding Covid-19, and it evaluated their approaches in dental procedures both before and during the pandemic. However, healthcare facilities are necessarily required for any society and are rarely closed under such pandemic conditions. Healthcare professionals are exposed to a higher risk of getting infected due to their close contact with potentially-infected patients. ${ }^{20}$ Dentists, in particular, perform their treatment procedures not only in close contact with patients but they also are exposed to aerosol and droplets from patients' oral cavities.8,20 Therefore, dentists have a high risk of getting infected from patients and potentially spreading it to their peers, families and other patients.

This study included a sample of dentists working in the KSA, with male dentists consisting of a greater share of the participants compared to female dentists. This is inconsistent with the results of some previous studies, ${ }^{10,21}$ but in agreement with another previous study. ${ }^{22}$ In a recent study, it was reported that the long questionnaire could decrease the response rate by the respondents., ${ }^{23}$ therefore, we tried to make the survey in this study short and comprehensive about Covid-19 pandemic. The response rate of this cross-sectional study was $52 \%$.

In the present survey, dentists' awareness about SARSCoV-2 was demonstrated clearly. Most of them stated that they knew the main symptoms of Covid-19, and half of the respondents knew the other symptoms. Additionally, the transmission modes of Covid-19 were identified by approximately $90 \%$ of the dentists in this survey. These findings are similar to the findings from a previous crosssectional study carried out with dentists in Jordan. ${ }^{10}$ In this questionnaire, $68.4 \%$ of the respondents knew that the incubation period was 2 - 14 days, which was confirmed by the CDC. Gaffar et al. ${ }^{22}$ reported that $<50 \%$ of dentists of their study in Saudi Arabia knew about the virus incubation period of MERS which did not match with the results of the present study.

A previous study regarding MERS-CoV carried out with dental students in Riyadh, Saudi Arabia, showed that the majority of the respondents knew the correct incubation time of MERS-CoV and this was in agreement with our study. ${ }^{24}$ Similar to the results of recent surveys carried out in Saudi Arabia regarding MERS, ${ }^{25}$ and in Jordan regarding Covid- 19,10 the results of the present study showed that the majority of the respondents were aware of the transmission modes of Covid19.

The results also showed the dentists' awareness of measures to prevent infection transmission in dental clinics, both before and after the outbreak of the SARS-CoV-2 pandemic. Three hundred ninety-four dentists stated using surgical masks before the pandemic. This number decreased during the pandemic, and the use of N95 mask increased (72.3 $\%)$. Dentists' use of other protective equipment such as eye protection glasses, disposable lab coats, face shields, dental caps and shoe covers increased after the pandemic outbreak. Approximately $96 \%$ of the dentists stated that they do not leave the clinic with the same lab coat during the pandemic. Relatedly, Khader et al. ${ }^{10}$ stated that personal protective equipment like dental goggles, masks and gloves are used by $92.9 \%$ of the dentists in Jordan during the pandemic, and the use of facemasks by dentists in Jordan has increased since the start of the outbreak. Additionally, the working hours of 300 respondents in this study decreased after the pandemic broke out.

During the outbreak of Covid-19, dentists should evaluate the risk of transmission by measuring the temperature of every staff member twice a day according to the guidelines of WHO and CDC. $14,1546.4 \%$ of the participants measured the temperature once a day and $47.8 \%$ measured temperature twice a day. According to ADA recommendations, only the dental procedures of emergency cases should be performed during Covid-19 pandemic period.

The results of this study showed that most of the dentists (81.1\%) performed procedures only for the emergency cases (pain, swelling or trauma), while $31.6 \%$ stopped all dental procedures during Covid-19. A previous study on emergency dental procedures and Covid-19 shared similar findings to those in this study. ${ }^{21}$ More than $80 \%$ of the participants in the present survey stated that they apply the infection control measures recommended by CDC and WHO like allowing only the patient to enter the clinic (without their relatives), checking the patient's temperature and asking about any Covid-19 symptoms within 14 days, avoiding as much as possible the use of devices that produce aerosol, using heat sterilisation of the handpiece after every patient, and providing sufficient ventilation after every patient in the clinic.

In addition, majority of the dentists followed the preventive measures when using devices that produce aerosol. These measures, recommended by ADA, include using a 4-handed technique, high vacuum suctions and a rubber dam. These results were in agreement with the results of previous cross-sectional studies. ${ }^{10,22}$ A 4-handed technique is useful for infection control, and the use of saliva ejectors with low or high volume suction reduces droplets and aerosol production. ${ }^{8}$

The use of a rubber dam is an effective way to control cross-infection by limiting the spread of aerosols, with good patient acceptance for dental procedures. ${ }^{26}$ The use of highvolume suction is also considered an essential means to control aerosol evacuation during dental procedures and should be used for majority of patients. ${ }^{11}$ Rinsing with mouthwash containing anti-viral agents (such as povidoneiodine) at the start of any dental procedure has been effective against various respiratory viruses. ${ }^{27}$

Our study had some limitations. First, the cross-sectional nature of the study can only prove association and not a cause-effect relationship. Second, the study was subjected to selection bias and sampling error, as participants were approached using social media, dedicated mailing lists and forums.

Thirdly, the relatively low response rate resulted in a smaller than expected sample size. This could have been due to the short period of data collection. However, this is considered a moderate sample size. 


\section{CONCLUSIONS}

Within the limitations of this study, the results showed that the majority of dentists in this survey had high knowledge and awareness of Covid-19. Most of them followed the recommended preventive measures in their clinics. As the KSA still suffers from outbreaks of Covid-19 infection, continuous assessment of healthcare professionals' knowledge and practices especially among dentists is crucial.

Data sharing statement provided by the authors is available with the full text of this article at jemds.com.

Financial or other competing interests: None.

Disclosure forms provided by the authors are available with the full text of this article at jemds.com.

\section{REFERENCES}

[1] Dong E, Du H, Gardner L. An interactive web - based dashboard to track COVID - 19 in real time. Lancet Infect Dis 2020; 20(5):533-4.

[2] Mahase E. China coronavirus: WHO declares international emergency as death toll exceeds 200. BMJ 2020;368:m408.

[3] Gorbalenya AE, Baker SC, Baric RS, et al. The species severe acute respiratory syndrome-related coronavirus: classifying 2019-nCoV and naming it SARS-CoV-2. Nat Microbiol 2020; 5(4):536-44.

[4] Zhai P, Ding Y, Wu X, et al. The epidemiology, diagnosis and treatment of COVID-19. Int J Antimicrob Agents 2020; 55(5):105955.

[5] Wax RS, Christian MD. Practical recommendations for critical care and anesthesiology teams caring for novel coronavirus (2019-nCoV) patients. Can J Anaesth 2020; 67(5):568-76.

[6] Rabaan AA, Al-Ahmed SH, Haque S, et al. SARS-CoV-2, SARS-CoV and MERS-COV: a comparative overview. Le Infez Med 2020;28(2):174-84.

[7] Asaad A, El-Sokkary R, Alzamanan M, et al. Knowledge and attitudes towards Middle East respiratory sydromecoronavirus (MERS-CoV) among health care workers in South-Western Saudi Arabia. East Mediterr Health J 2020;26(4):435-42.

[8] Meng L, Hua F, Bian Z. Coronavirus disease 2019 (COVID19): emerging and future challenges for dental and oral medicine. J Dent Res 2020;99(5):481-7.

[9] Guan WJ, Ni ZY, Hu Y, et al. Clinical characteristics of coronavirus disease 2019 in China. N Engl J Med 2020;382(18):1708-20.

[10] Khader Y, Al Nsour M, Al-Batayneh OB, et al. Dentists' awareness, perception and attitude regarding COVID-19 and infection control: cross-sectional study among Jordanian Dentists. JMIR Public Health and Surveill 2020;6(2):e18798.

[11] Ge ZY, Yang LM, Xia JJ, et al. Possible aerosol transmission of COVID - 19 and special precautions in dentistry. J Zhejiang Univ Sci B 2020;21(5):361-8.
[12] Peng X, Xu X, Li Y, et al. Transmission routes of 2019-nCoV and controls in dental practice. Int J Oral Sci 2020;12(1):9.

[13] Thomas MV, Jarboe G, Frazer RQ. Infection control in the dental office. Dent Clin North Am 2008;52(3):609-28.

[14] World Health Organization. Clinical management of COVID-19: interim guidance. https://www.who.int/publications/i/item/clinicalmanagement-of-covid-19.

[15] Centers for Disease Control and Prevention. CDC recommendation: postpone non-urgent dental procedures, surgeries and visits. https:// www.cdc.gov/oralhealth/infectioncontrol/statementCOVID.html.

[16] The American Dental Association. America: The association. ADA interim guidance for minimizing risk of COVID-19 transmission. https:// www.ada.org/ /media/CPS/Files/COVID/ADA_COVID_I nt_Guidance_Treat_Pts.pdf.

[17] World Health Organization. Who Coronavirus Disease (COVID-19) Dashboard, Global, Saudi Arabia. https:// covid19.who.int/region/emro/country/sa

[18] World Health Organization. WHO Coronavirus Disease (COVID - 19) Dashboard. https://covid19.who.int/.

[19] The American Dental Association. America: the association. Interim mask and face shield guidelines. https://success.ada.org/ /media/CPS/Files/COVID/AD A_Interim_Mask_and_Face_Shield_Guidelines.pdf.

[20] Ather A, Patel B, Ruparel NB, et al. Coronavirus disease 19 (COVID-19): implications for clinical dental care. J Endod 2020;46(5):584-95.

[21] Ahmed MA, Jouhar R, Ahmed N, et al. Fear and practice modifications among dentists to combat novel coronavirus disease (COVID - 19) outbreak. Int J Environ Res Public Health 2020;17(8):2821.

[22] Gaffar BO, El Tantawi M, Al-Ansari AA, et al. Knowledge and practices of dentists regarding MERS-CoV. A crosssectional survey in Saudi Arabia. Saudi Med J 2019;40(7):714-20.

[23] Sahlqvist S, Song Y, Bull F, et al. Effect of questionnaire length, personalisation and reminder type on response rate to a complex postal survey: randomised controlled trial. BMC Med Res Methodol 2011;11:62.

[24] Almutairi MA. Awareness about middle east respiratory syndrome-corona virus (MERS-Cov) among dental students in Riyadh, Saudi Arabia. Pak Oral Dent J 2016;36(3):426-9.

[25] Alqahtani AS. Knowledge and attitude toward Middle East respiratory syndrome coronavirus among heath colleges' students in Najran, Saudi Arabia. Int J Community Med Public Health 2017;4(8):2641-7.

[26] Madarati A, Abid S, Tamimi F, et al. Dental-dam for infection control and patient safety during clinical endodontic treatment: preferences of dental patients. Int J Environ Res Public Health 2018;15(9):2012.

[27] Kitamura T, Satomura K, Kawamura T, et al. Can we prevent influenza-like illnesses by gargling? Intern Med 2007;46(18):1623-4. 